\title{
1 The delusion of the global corporation: introduction to the Handbook
}

\author{
Christian May and Andreas Nölke
}

Over the last couple of decades, the global corporation has become a myth in international political economy (IPE) scholarship. Multinational corporations ${ }^{1}$ (MNCs) were seen not only as the leaders of the world economy, via an intricate net of cross-border investments, but also as powerful global players, as lobbyists and as rule-makers. At times, corporations have been understood to be on a par with states with regard to their authority (Stopford and Strange 1991). In the heyday of the globalization debate, firms have even been portrayed as being even more powerful than states, especially when it comes to the ability to shape the course of the global economy. This mythical image of the global corporation has been supported by a strong public focus on very large multinationals such as Shell, Apple, Nestlé, Microsoft, Google and others which (too often) are pictured as representative of the whole economy. Research on MNCs very often focused on corporations' growth in size, sales or transnationality, often as an indicator for 'globalization'. Studies of transnational production and of localization strategies reinforced the interpretation of large corporations being able to devise their corporate strategies at their full discretion, independent from political, social or environmental objectives.

Corporations have also become 'mythical' because IPE scholars have rarely studied firms in their own right. What firms are, how they behave, their goals and constraints, have been stowed within a 'black box' that largely remained neglected within IPE. Though the power of corporations, along with that of states, has been recognized, it did not lead to a field of research where firm-level data would be analysed with the same care as country-level data, or where chief executive officers (CEOs) and directors of large firms would be interviewed and their behaviour analysed in the same way as for state leaders and ministers. What corporations want, and how they go about achieving it, has often been deduced from macroeconomic and political structures - in the same way as neorealism did with the analysis of states.

This myth of the global corporation has to be qualified. As many contributions to this Handbook demonstrate, big corporations are much more strongly dependent on their national institutional context than is assumed by this 'global corporation saga'. Once we look closer at corporate realities, whether through the analysis of corporate governance structures, investment patterns, production strategies or the different roles that firms play in national and global arenas, we regularly observe a common trait: that firms are by no means 'autarkic' (in the sense of being fully autonomous and independent), but have to carefully manage their relationship with their social and political environments - with states, but also with other firms. Moreover, the implicit assumption that the globalized shareholders and managers of these corporations are in fact the undisputed leaders of the global economy underplays the role of other stakeholders, including workers and the public at large. 
This calls for an IPE of the corporation that actually engages in the analysis of firms in their own right. If we stick for one moment to the idea of analysing firms in the same way as states, we find support for appropriate strategies to learn more about them. Approaches that aim to take state preferences seriously (Moravcsik 1997) or that explain the international political economy through the analysis of states' foreign economic strategies (Katzenstein 1978) both assume that those preferences vary depending on internal political formations. As a first step, we can think of a similar 'two-level game' analysis of firms, where the global behaviour of firms might be explained by investigating their internal structure, their goals and strategies (see Morgan, Chapter 17 in this volume). It then becomes clear that firms have a range of goals and interests beyond the simple pursuit of profit; interests which include the long-term sustainability of their business, handling the competitive pressures in a specific market, and the distribution of power within the firm. Looking at the internal constitution of firms (Part I of the Handbook) helps to grasp these sometimes conflictual interests.

However, the global corporation needs demystification not only because of its status as a 'black box' of IPE analysis, but also for empirical reasons. The international expansion of firms seems to be slowing down and we can observe a growing 're-nationalization' of corporations around the world. Correspondingly, the national context of firms becomes even more important (see Part II of the Handbook). Global enterprises tend to transnationalize less than previously, as their foreign activities, such as sales, employment and investment, grow more slowly than in the period before 2010 (UNCTAD 2017a, p. 26). Such trends even lead The Economist to claim that the "world is losing its taste for global businesses' (The Economist 2017). By thinking in terms of push- and pull-motivations for firms to transnationalize, we can address some reasons for this trend.

First, transnationalization no longer seems to pay off in the same way as it did in the 1990s and 2000s. Either costs for further expansion have risen disproportionally, or revenues have shrunk in a way that has made cost-related transnationalization unproductive. These costs also include efforts to effectively organize the transnational firm, to organize effective control over the value chain, to bargain with host countries over the size and style of their foreign activity, the costs of adjusting to different legal and political environments, as well as the risk of losing control over relevant knowledge where MNCs use contracting firms down the production chain (see the chapters in Part III of the Handbook, particularly Chapter 16 by de Beule and Jaklič, Chapter 17 by Morgan, and Chapter 18 by Bakir and Woods, as well as Chapter 26 by Campling and Selwyn in Part IV). These costs can amount to factors that push firms out of transnationalization, in particular when capital to undertake such projects is scarce, such as after the credit crisis of 2008. Second, another push factor is the rising competition of firms from within host countries. Such firms are often explicit instruments of governments aimed at boosting industrial development, as in recent versions of state capitalism. These new competitors are sometimes also the results of MNCs quickly rearranging their production chains and shifting production locations from one place to another. Yet, contractors, suppliers and workers retain the knowledge of producing particular goods, which can become the nucleus of independent firms that operate in the same segment (albeit, at first, not on the same level of quality). Third, the main pull factor these days is the decision of Western businesses and governments to relocate production facilities within their home territories. A well-known reaction in times of crisis, the public might ask why 'their' national firms 
create jobs abroad while unemployment rises at home, especially in manufacturing. From a global view, this strategy reflects the practice of emerging economies to support their industries. However, its novelty lies in the observation that Western countries now seem to be in need of such remedies as well, as prominently indicated by United States (US) President Trump.

These push- and pull-dynamics change the global corporate landscape, with more wideranging consequences and implications than are usually accounted for. As businesses become more 'national', the prospects for the international governance of trade, investment, corporate social responsibility (CSR) and global governance in general are hard to forecast (see Chapter 19 by Ganson and Wennmann, Chapter 20 by Berge and Hveem, Chapter 22 by May, Chapter 23 by Kinderman, Chapter 24 by Young, and Chapter 25 by Eckhardt). However, the global political economy in general, and in particular the position of private firms in it, have always been moving from a primarily international towards a transnational or global arrangement, and vice versa. In fact, there has never been a continuous path towards a 'global political economy' driven by technology or telecommunication, but there have always been nationally oriented forces that compete with or struggle against globally oriented forces or fractions. An international political economy of the corporation should be able to account for these different trajectories. It is in fact a misconception to think of IPE as dealing exclusively with the global dimension of the activities of corporations; there is also a rich literature on comparative analyses between politico-economic systems (see Clift 2014 for a useful summary). This also becomes obvious if we look at the history of the study of the corporation in IPE.

\section{THE STORY SO FAR: ASSESSING THE CONTOURS OF CORPORATE POWER}

The power of the corporation vis-à-vis politics had been a subject for many years before it entered the realms of IPE (a classic example is Lindblom 1977). Private corporate power constitutes a potentially political problem because it can be argued that it brings about unfair benefits at the cost of citizens, suboptimal policy-making and implementation as well as dangers of rent-seeking by those business forces that are able to 'capture' the state (Coen et al. 2010, pp. 11-12). When international trade and investment were dramatically eased during the 1970s and 1980s, firms became active on a transnational scale, which has made the original problem of the power of corporations a matter for the study of IPE. Moreover, it brought a new set of problems that were not just about the effectiveness or legitimacy of policies (largely being problems of democratic accountability), but about state sovereignty. The power of corporations to direct their resources and activities away from their home bases towards other countries could not be controlled in the same way as through national legislation, thereby making the transnational activities of enterprises a form of private foreign (economic) policy.

In the 1960 s and 1970 s, IPE scholars increasingly started to pay more attention to the role of transnational corporations, because they had the capacity to operate across borders and the states they were active in had only limited control over their actions. Even more, MNCs had the power to shop for the best conditions to pursue business, forcing states into a competitive run for foreign direct investment (FDI), because investment of 
foreign capital is associated to jobs and tax revenues. As a consequence, IPE analysed firms as similar to states because both had the capacity to determine the 'who gets what' in the global economy. For some, the rise of global production networks and global finance eventually shifted the balance of power dramatically away from states and towards private business (Strange 1996, p. 4).

The power of transnational corporations is usually illustrated by depicting their size vis-à-vis states, or their degree of transnationality. The first measure, the sheer size of many MNCs, challenges the classical realist argument that the most powerful actors in the world are states. Comparing gross domestic product (GDP) to value-added sales, ExxonMobil or General Motors were 'larger' than Pakistan, Chile or the Czech Republic in 2000 (Fuchs 2007, p. 54). If GDP and revenues are compared, Wal-Mart was the 25thbiggest economic entity on the globe in 2007, larger than Denmark or Portugal (Wilks 2013, p. 7). And more recently, comparing GDP and enterprise market value, Apple was 'worth more' than Switzerland and Saudi Arabia in 2016 (UNCTAD 2017a). Obviously, such measurements are imprecise and questionable, but they serve as an illustration of the 'monster' that many MNCs are. Too often, however, the sheer size of MNCs has been equated with the power of MNCs, whether actual or potential.

The other popular, and perhaps more reliable indicator of $\mathrm{MNC}$ power is their degree of transnationality, as it captures the exit options corporations have vis-à-vis their host countries. In an abridged form, this is captured in the United Nations Conference on Trade and Development (UNCTAD) Transnationality Index (TNI) which captures the degree to which sales, assets and employment are located outside a firm's home territory, with a score of 100 denoting the most transnational enterprise possible (UNCTAD 2007, p.13). While the top $100 \mathrm{MNCs}$ had an average TNI score of 51 in 1990, this gradually rose to 65 in 2015 (UNCTAD 2017a, p. 27). This indicates that, indeed, large MNCs have become more transnational, although the expansion of foreign assets, much more than sales or employment, drove the increase in transnationalization.

While for some corporations it is more 'natural' to invest abroad than for others, transnationality essentially refers to the ability of corporations to use 'exit options', that is, to exercise their power to circumvent national regulations if necessary. A corporation is simply less affected by political decisions in one country if it has production facilities in 20 countries. Most important, however, are the stocks and flows of FDI. The fact that companies were locating their production facilities abroad was at the heart of the initial argument that this activity has deeper impacts on national economic systems than international trade. Thus, when it comes to the role of corporate power, it is the component of foreign assets (rather than foreign sales or employment) that is the most important factor, because foreign investment (that is, the deployment of capital) has an immediate effect on a host economy. Firms invest abroad in order to gain control over the production process in another country, whether in the form of acquiring foreign firms or by setting up facilities themselves. From the mid-1980s on, FDI grew much more strongly than trade (Dicken 2011, p.21), indicating the growing ability of firms to organize production on a global scale and the shrinking power of states to regulate the flows of goods and capital by way of tariffs or capital controls. While the share of FDI compared to overall capital formation remained low during the 1970s and 1980s (about 2.5 per cent), by 2015 it represented more than 13 per cent of all capital formation made by firms located in developed countries (UNCTAD 2017b). There is thus an increasing trend for firms to 
invest not at home, but abroad; with all the associated effects on employment, social security and public budgets.

Again, these figures serve only as a rough indication of the extent to which firms engage transnationally, regardless of their motivations and strategies. It is not, however, a measure of 'MNC power', although much IPE research on MNCs tends to feed this interpretation, especially earlier realist analyses (such as Gilpin 1975). Corporations have been viewed as instruments of national power and their activities as a way of employing foreign policy. MNCs first and foremost invested in countries with difficult market access in order to substitute for the trade of goods. Those markets, however, were under national control (by way of tariffs, competition and industrial policies, and so on) and the activities of MNCs could be interpreted as interference of foreign countries in the economic policy of sovereign states.

It would take another 20 years to dismantle this instrumental view on MNCs. By the mid-1990s, the dominant view within IPE stated that 'corporations rule the world' (Korten 1995), and states could usually only passively adapt to their rule (for a critical account, see Doremus et al. 1998). As they became ever more transnational, MNCs lost their allegiance to their country of origin and pushed for profitable opportunities wherever they found them. Ironically, they remained associated with their national home base in the public view, where takeovers of United Kingdom firms by US companies or, more recently, 'Western' firms by Chinese corporations, are still treated as a matter of national interest. Nevertheless, the issue of the power of the corporation has remained a crucial topic in IPE.

\section{Measuring Corporate Power}

Based on the discussion about the indicators above, it becomes clear that we can only speak about MNC power in principle. Size and transnationality might enlarge the options for corporations, but they might also be a result of enforced competition. No few mergers and acquisitions (M\&As) are motivated by the fear of being taken over by another company in the first place; not by an explicit expansive business model. Hence, these indicators describe at best the potential power of firms, not the actual possession or exercise thereof. Analytically and politically, it is also relevant whether the power of corporations is intentional or structural.

These two views have been prominent strands within discussions about corporate power (for a good account, see Fuchs 2007; on the measurement of power, see pp. 52-56). In danger of oversimplifying, the classic statements about corporate power formulated by Lindblom (1977), Gilpin (1975) and Strange (1996) argued from a structural power perspective. For Lindblom, public authorities were crucially dependent on the well-being of firms, which gave the latter a structural advantage for the pursuit of their goals. In a very similar fashion, Strange argued that in the late twentieth century states depended on the resources of private actors in order to fulfil their political objectives in areas such as security and welfare. As states tend to be permanently indebted, they would be in need of FDI, if only to balance their current accounts and to stabilize their currencies (Strange 1998). Facing this dependency, states would be in a weak position to bargain for and against particular types of investments, thresholds or local content clauses. Yet, as appealing as this argumentation is, it is derived from the structural features of 


\section{Handbook of the international political economy of the corporation}

the international political economy, not the preferences of corporations. Stretching the market analogy to the international political economy, some scholars attributed the power shift between business and politics to 'changes in relative prices' (Frieden and Rogowski 1996, p. 29). In a realist fashion, firm behaviour is deduced from the properties of the international economic structure in the same way as the behaviour of states could be inferred from the power structure in international politics (Gilpin 1975, 1987). The main difference between corporations and states is, however, that the latter's preference (within the realist framework) is security, which requires a limited set of foreign policy options. In turn, corporations' main goal is the pursuit of profit, which can, however, be realized in multiple ways that might or might not involve transnational investment. Additionally, corporations might have a security interest too, so as to protect the existence of the firm against takeovers or short-term rationalities. Thus, a structural approach to corporate power offers valuable pathways to explain the behaviour of firms in the global political economy, yet it fails to explain it completely. In between the international economic system and the actual actions taken by corporations lies a 'black box' in which external incentives, managerial choices, firm strategies and political influences eventually shape the course of action that firms take (see Gourevitch and Shinn 2005). Whether a corporation takes advantage of structural power resources or not, and whether intentionally or not, are important questions that need to be addressed in order to make valid propositions about corporate power.

The alternative approach would focus on exactly those preferences of corporations. It would posit that corporations gained influence because they explicitly aimed at increasing their power. Changes in the international political economy provided corporations with opportunities to enlarge and diversify their options for profit which reach beyond the 'agreement' of governments and managements to work in concert for their common (national) interests. Increasing their power, then, has been a project of the corporations in itself, and for this they would strive to gain more influence in hitherto unrelated areas and sectors. Crucial for such projects are concerted elite efforts to shape and transform the means of economic governance and policy-making. In this view, corporations do not simply 'outgrow governments' (Strange 1998), but take advantage of both national linkages and transnational organization.

Following this perspective, research on transnational business communities over the last two decades demonstrates how corporate elites link up on an international level (Carroll 2010; Murray and Scott 2012; Heemskerk and Takes 2016). Some authors argue for the existence of a 'transnational capitalist class' which comprises not only business elites but also politicians, bureaucrats, professionals and the media (Robinson and Harris 2000; Sklair 2001). However, it is important to differentiate analytically here: are elite networks predominantly of an inter-corporate kind, or are they intrinsically expanding into other spheres of public life? For our purposes, the latter is more interesting. The former would be a case of 'capital concentration' by concertation; that is, the effort to align individual corporate preferences and to foster the organization of transnational business as a corporative actor. The latter, however, would represent the growing conflation of public and private interests, the expansion of the corporate power base by means of integrating public elites.

Yet, definite proof of such effective coordination is lacking. The simple fact that elites are meeting on an international scale does not allow the conclusion that such meetings 
are de facto indispensable for the success of MNC strategies (see Graz 2003). For this reason, it is also not (yet) time to speak of a transnational capitalist class, if class is not simply reduced to a group of people but constitutes a qualitatively necessary factor for the shaping of political economies. We simply do not know whether the transnational organization of business elites is actually a necessary condition for the success of MNC strategies. Several arguments call for greater care: first, individual corporations, especially the large global MNCs, stand in fierce competition to each other. This is of course also the case for 'national' capitalists, but the case for a transnational capitalist class is founded upon the elites of large MNCs. But for those corporations, their power might not be a result of effective organization, but derive from the concentration of capital and related oligopolistic effects. Second, many MNCs are highly profitable without being enmeshed in transnational business communities. The CEOs of the bulk of successful MNCs from emerging economies are not part of a global capitalist class. Compared to their market power, CEOs from Chinese MNCs, for example, feature disproportionally low on the guest lists of clubs such as the World Economic Forum.

In order to make a valid statement about the role of transnational organization for the power of corporations, one would have to show: first, that such transnational organization is necessary for effective corporate strategies; and, second, that this particular transnational organization brings about qualities which the national organization of business interests could not deliver. In other words, we would need 'non-successful' cases of firms; which are, as we know, hardly studied. By 'selecting on the dependent variable' - that is, major transnational firms and elites - we cannot prove that the mechanism of transnational organization is actually indispensable for the power of transnational capital.

In sum, this means that the formation of transnational business elite networks is at best a sufficient element for the power of corporations. For instance, it makes logically little sense for large, oligopolistic MNCs to engage in the creation of networks and alliances that allow for enhanced competition and free-rider behaviour in the first place. In our opinion, the important facets of corporate power are of a structural kind. As such, they are not the result of intentional corporate activity but result from a configuration of various actors, institutions and organizational logics. Yet it is in this configuration that the power of corporations regularly becomes compromised. Correspondingly, we should not generalize about the power of the global corporation, but rather look at specific executions of this power.

\section{Differences among Firms and Corporate Power}

The move towards the actual analysis of firm behaviour and corporate power came from strands of research that were not explicitly critical in a theoretical sense. Marxists by and large followed a structural approach similar to neorealism: the preferences of actors can be inferred from the system in which they are located. Hence, scholars from Marxist or Gramscian IPE referred not to corporations, but to 'capital' (Gill and Law 1989), just like realists and institutionalists would refer to 'markets' as the main force that undermined the authority of states and governments (see, of course, Strange 1988, 1998). In the same way, regulation theory referred to abstract regimes of accumulation, also assuming that the laws and rules of capital accumulation apply across firms more or less in similar ways.

At the same time, however, comparative political economists began to specify differences 
among corporations in at least two areas which became ever more important in the 1980s and 1990s. The first was the spatial dimension. Apart from the well-known differences of European vis-à-vis US firms, the unique nature of the Japanese corporation attracted much attention (Dore 1973; Aoki and Dore 1994; Witt 2014). The message it presented to the IPE community was clear: in order to understand the power of Japanese firms, both domestically and abroad, one has to understand their internal logics and organization. In terms of its internationalization strategy it made a huge difference whether a firm was of American or Japanese origin, and it would be a gross misinterpretation to subsume both under a common universal logic of capital. Although this comparative and case-analytical approach acknowledged the rising power of transnational capital, it also pointed out some concrete trajectories through which corporate power (or the lack thereof) would be exercised (Keohane and Milner 1996, pp. 15-22). An important corollary of the close analysis of the German and Japanese cases (see, e.g., Yamamura and Streeck 2001) was the general idea that firms are by no means solitary or self-sufficient entities, but organizations that draw upon other institutions in order to be effective. The success (and power) of corporations is determined not only by management decisions but also by the kind and extent of support through their social and political environment. German and Japanese firms crucially depend(ed) on preferable access to large national banks, on favourable relations with labour organizations, and on effective education and training schemes; all of which are beyond the direct influence of firm managements. As a consequence, comparative political economy scholars developed a typology of regionally distinctive business systems (Whitley 1999; see also Chapter 11 by Witt, Chapter 9 by Eckert, Chapter 10 by Šćepanović and Bohle in Part II of this Handbook).

The sectoral dimension constitutes a second area in which corporations can be differentiated meaningfully. Here, the difference between manufacturing and financial firms is of crucial importance. The initial discussion about MNC power focused on manufacturing corporations exclusively, which is why the issue of MNC control was of particular importance for developing countries where Western corporations would crowd out local jobs and industries. However, in particular since the 1980s, FDI by financial firms (banks, investment funds, institutional investors, and so on) have become an important aspect of the global political economy (see Young, Chapter 24 in this volume). While limited capital mobility previously allowed for FDI but has mainly been used by classic enterprises (for example to acquire other firms), it now became increasingly a matter of professional investors. While we will turn to the wider implications of financialization for corporations below, here we want to highlight the impact it has on the analysis of corporate power. Reduced capital controls, increased liquidity in global financial markets and a move towards marked-based corporate finance (mainly through stock exchanges) led to the rise of financial firms that strongly shaped the contours of the global political economy. Unlike 'classic' FDI, which has been motivated by particular business strategies, the logic of financial firms is distinctively different as they first and foremost invest in companies which promise an increase in firm value (and with it, investors' return on investment). As a general thrust, FDI by manufacturing firms is more likely to be of a long-term orientation, while FDI by and through financial firms usually comes in the form of portfolio investment and is therefore much more guided by short-term considerations. It is here that the difference between these two classes of firms matters most for the evaluation of corporate power. 
These two dimensions, the spatial and the sectoral, indicate crucial differences among corporations and highlight the inadequacy of frameworks that treat firms and markets alike. The question then remains: how can we be sure that individual capitalists actually behave in the way theories of transnational capital argue? Or perhaps even more complicated: how can we deduce the actual behaviour of firms from the general properties of globalized markets, especially in the light of diverging outcomes on the 'dependent variable', that is, the behaviour of corporations (as witnessed with, for example, Japanese firms)? It is here that the need for a more nuanced and comparative approach becomes visible.

Astonishingly, Susan Strange initially offered an intuitive approach that would take corporate preferences seriously. Her argument for a 'triangular diplomacy approach' emphasized the rising power of corporations without them overpowering the political sphere (as was the case in her later works; see Strange 1996, 1998). Thinking about analysing the behaviour of corporations and states by way of three sets of diplomatic bargaining relations - state-state, state-firm and firm-firm - offered an entry point towards the empirical study of actual firm behaviour from an IPE perspective (Stopford and Strange 1991; Strange 1992). It did not just point out that relations between firms and states are essentially bargaining situations, that is, that there would be always a give and take between both poles; it also directed attention to the hitherto neglected dimension of firm-firm bargaining. This opened the way to study how firms regularly have different interests and preferences, if only due to the fact that they are competitors for market shares or portions of the value created in transnational production chains (see Campling and Selwyn, Chapter 26 in this volume).

Acknowledging the simple fact that corporations are each other's competitors adds a further question mark to the assumption that all individual firm interests can be subsumed under the corporate interests of 'business' or 'capital' as such. Obviously, it makes sense to assume that firms would act in similar ways to outperform their competitors (such as lowering costs while keeping the mode of production or accumulation intact). However, firms are often able to outperform their competitors by changing their mode of production or accumulation through radical innovation of products and production processes (again, as the global ascent of the Japanese corporation, with its focus on innovative production methods and technological advance, demonstrates). Yet, the 1990s saw the dominance of IPE approaches that usually treated corporations as one undifferentiated and rather uniform group of actors across the global marketplace, while being insufficiently able to assess their power.

\section{LIMITS TO THE POWER OF GLOBAL CORPORATIONS}

As we have demonstrated, earlier research on MNCs suffered from a simplified idea of the corporation that it is mainly interested in expanding its scope across borders and to "colonize' foreign markets with universal products, services or corporate styles. This fuelled an image of globalization in which location does not matter because cars, hotels, drinks and fast food are all the same, no matter where one enjoys them. The power of MNCs then was largely the power to homogenize and to standardize, glossing over cultural and spatial differences, for good or bad. However, as we have argued, this picture is too simple and 
one-sided, as the nature of corporate power is much more complex. Firms nowadays tend to adapt to local conditions: on one hand, these might be particular market structures and consumer preferences, or special 'factor endowments' related to legal systems and tax regimes. Thus, there is more to it than a simple power struggle of corporations vis-à-vis states. Governments and other regulatory bodies can try to use their power to limit corporate influence, but they often also empower corporations if it suits their political interests. On the other hand, corporations do not always seek to emancipate themselves from the regulatory grip of states, but often explicitly aim to fall under specific jurisdictions (for example, to benefit from regulatory arbitrage or to enjoy legal security).

IPE also tended to overstate the effectivity of MNCs in organizing their power and authority. As organizations grow, the costs of maintaining these entities also grow, and this is no different for corporations. As we argued earlier, there is no reason to think of a linear association between transnationalization, size and power. Morgan, for instance, indicates in his contribution (Chapter 17) how difficult the organization of effective inter-office relations can be, and how this often does not bring about the results which the headquarters (HQ) management wanted to achieve. Recent business history is full of unsuccessful transnationalization projects of Western MNCs which are due to corporations' inabilities to effectively 'stretch out'. Similarly, corporations have been successful in establishing transnational networks and standards, yet we usually point towards those cases which proved to be effective (such as the standard-setting practices in corporate finance and securities trading). But since standard-setting is very often a competitive endeavour (see Chapter 28 by Graz), it can become costly, while the benefits are not certain.

These are general caveats against the myth of the powerful global corporation. More recently, however, empirical developments are indicating that the nature of the corporation is changing. We will discuss three of these developments below. First, the shift to shareholder value-oriented corporate governance and finance (financialization) compromises managerial autonomy, which in turn has dramatic effects on how corporations organize, both within the firm and in relation to their economic, political and legal contexts. Second, public economic policies are shifting, from general economic frameworks (structural reforms) to the direct assistance of individual companies ('pro-business' economic policies). In a realist sense, corporations are increasingly becoming national (or foreign) economic agents again. Third, governments more comprehensively impose their national priorities on company strategies, a move that points towards a paradigm shift from liberal towards organized capitalism. In this vein, the resurgence of mercantilism and protectionism also limits the power of the global corporations regarding political decisions, both with regard to the management of global wealth chains as well as with regard to global policy-making.

\section{Financialization and Changes in the Business Landscape}

The rise of financialization has added another dimension of power relations that cuts across the power relations between corporations and states. Financialization, which refers to the growing systemic importance of financial capital and the associated logics of investment and accumulation, is probably one of the most defining transformations of the political economic landscape around the globe. The possibility to move billions of dollars 
in the form of liquid financial capital around the globe provides new threats as well as opportunities for both states and firms. States, chronically indebted, provided incentives to attract FDI, even if such flows would only be stored in national bank accounts in order to reap interest dividends; while firms were able to attract huge amounts of capital to allow growth and expansion at a much faster rate. Because transnational financial capital comes in a flexible and liquid form largely unhindered by capital controls or otherwise, it provides quick financing at relatively low cost, and corporations and states do not need to develop sustainable economic strategies to raise or generate such funds internally (in the fashion of retain and reinvest). However, this form of financing has also added a new level of uncertainty to businesses, since investments are increasingly based on external credit, thereby increasing a firm's dependency on 'other people's money'. Furthermore, as much financing is now no longer conducted through traditional bank loans but through shares, bonds or other types of securities, corporations (and states) became more and more subject to market volatilities.

While traditional M\&A is strategically oriented, with a medium- or long-term perspective, financial portfolio investment follows the 'shareholder value' logic and is usually short-term-oriented. Increasing investment by financial firms led 'target firms' to reorient their business strategies towards the pursuit of high firm values (stock prices) while becoming exposed to the volatilities that are associated with being traded on the 'market for corporate control'. Further innovation in the financial sector allowed corporations to attract ever more capital and to achieve greater leverage on their investments, while interfirm competition forced corporations to increase their external capital base in order to keep up with competitors. To meet their financing goals, they would increase their capital base not just by means of listing on stock exchanges, but also through issuing corporate bonds and other forms of corporate securities. All of these developments led to growing debt-to-capital ratios, thereby increasing the vulnerability of corporations against sudden measures by shareholders and investors. This vulnerability associated with financialization is strikingly illustrated by the case of General Motors, which in 2000 had been one of the largest corporations worldwide, only to become bankrupt in 2009.

In this light, it is hard to maintain the idea of the omnipotent global corporation if even the largest MNCs are actually subject to investor power. This power translates in the growing dominance of corporate governance mechanisms and institutions that ensure firms' compliance to the shareholder value principle; the rise of rating agencies being probably the most important expression of the power shift from firm managers to investors. As their analyses and decisions have direct effects on the market prices of corporations, as well as on the costs for external credit, they exercise power in the bluntest sense. Corporations orient their firm strategies first and foremost to acquiring high rankings and high stock prices, which leads them ever more to use their capital for share buyback operations; capital that would otherwise be used for investments in productive facilities or innovation.

Ironically, the increased power of shareholders makes the national embeddedness of MNCs important again, as financial investors demand security for their investments that eventually only national states can guarantee. Supervisory bodies like the Securities and Exchange Commission (SEC) in the US enjoy a high reputation of protecting investor rights, which is why corporations seek to list their shares on the New York Stock Exchange, as it improves their access to external capital. In that way, corporations have to adapt to 
different legal and political conditions, which is particularly severe for enterprises which traditionally had other schemes of corporate governance that were not primarily oriented at dispersed shareholdings. However, this opens the opportunity for national states to engage in competition for regulatory standards that meet the demands of transnational investors. Again, this development heavily qualifies the power of Western corporations (if understood as the autonomy of corporate strategy).

\section{The Contemporary Shift towards Pro-Business Economic Policies}

Economic policy around the world is changing. While it is often aimed at shaping the framework in which business takes place (tax systems, infrastructure, labour and education regimes, and so on), governments increasingly assist individual companies directly, for different reasons. While emerging economies use well-oiled relations between firms and bureaucracies to boost development, developed countries hitherto only resorted to this means of direct support in times of crisis, that is when businesses which were crucial to the overall national economy had to be saved from bankruptcy. Often, these primarily included corporations and the tens of thousands of associated jobs in large industrial districts. In more recent times, however, predominantly financial firms received direct state support, because they were deemed 'too big to fail' and bankruptcy would hypothetically - have been hazardous to the whole economy.

A decidedly pro-business (in opposition to a pro-market) strategy has been common in emerging economies such as China and India, amongst others (Nölke et al. 2015). This 'pro-business drift' marks a switch from the support of crucial economic sectors towards the support of crucial firms. For developing countries, this has been a reaction to the ineffectiveness of large-scale development strategies focused on whole industries. They were ineffective because they were strongly oriented towards developmental ideas of governments, but hardly towards the needs and wishes of individual firms. In contrast, in a pro-business strategy, governments approach selected firms directly to cater to their firm-specific interests. Consequently, selected firms enjoy state protection in exchange for the provision of jobs, taxes or other public goals. Such a strategy usually limits the competition between firms, which ensures that firms actually engage in large-scale investment rather than resting in a competitive stalemate, in which no firm wants to carry the burden of heavy investments alone.

However, we can observe a proliferation of pro-business politics in developed economies as well, albeit without the developmentalist programme. In many cases, the motivation is an implicit declining-industry argument: firms that are no longer profitable should be supported in order to keep associated jobs or to avoid the costs of bankruptcy. While there have been exceptions in strategic sectors (construction, energy, auto industry) before, the financial crisis of 2007-2008 brought state support for individual firms to a new level. As taxpayers in affected countries legitimately ask why manufacturing firms collapse while, for instance, the US Treasury provides US $\$ 700$ billion for bank bailouts, political forces outside the liberal orthodoxy easily embrace this scepticism and promise big money for manufacturing sectors in election campaigns.

At the time of writing in early autumn 2017, the newly elected Trump administration in the US seems to be following exactly such a pro-business strategy (Zingales 2016). Established corporations are approached directly, with the intention to change their 
corporate strategies, effectively knitting a web of firms that serve as an extension of US economic policy. In the long run, of course, this favours incumbent firms over newcomers, and politically 'connected' firms over independent ones, further blurring the line between the state and business that is characteristic for state-permeated capitalism (Nölke et al. 2015). However, as Sapinski and Carroll point out (Chapter 3 in this volume), this collusion of business and political elites is a prevalent feature of contemporary capitalism, and modern corporations would never keep themselves separate from the political sphere.

This movement towards closer proximity to national governments fits well into the observation that large corporations have become less 'transnational' (see above). The potential for expansion by transnational corporations has been shrinking, not least because emerging markets are less open for foreign capital than 10-15 years ago (Nölke et al. 2015). At the same time, we have seen the rise of large multinational enterprises from emerging economies which, despite being active around the world, draw more heavily on their home base. And as multinational firms cannot find profitable outlets to the same extent as they could in the 1980s and 1990s, they have to find their fortunes at home. In turn, this obviously makes corporations more sensitive to the demands of their home governments.

If this trend towards pro-business economic policies continues across different regions of the world, the (liberal) principle of non-interference between the political and the business world will come under question. Despite the frequent statements about state capitalism in emerging economies (see, e.g., Musacchio and Lazzarini 2014), one should not forget that most state-owned MNCs are from Europe, not from China, Latin America or anywhere else (UNCTAD 2017a, p. 31).

However, if public policy is increasingly oriented towards the well-being of single corporations - either by direct funding or by way of strategic support that is decided upon in closed meetings of state officials and managers - calls for stronger state control of corporations will become louder. Now that the time of big state interventions is coming ever closer, it is time to reconsider the nature and role of the corporation in the economy. Pro-business politics, for instance, support corporate HQs at the expense of branches and suppliers. Therefore, some chapters in this book analyse the potentially conflictual nature of corporate relations, either within the global value chain (GVC) or even within corporations themselves (see Chapter 22 by May, and Chapter 17 by Morgan, in this volume). Just as the image of the unitary state is misleading, so is the image of the unitary firm.

\section{Public Corporations beyond States and Markets: From Liberal to Organized Capitalism}

Now, in these post-globalization times, the 'global corporation' is losing ground and the differences between firms and their strategies are becoming more apparent. As we argue, these are becoming 'national' enterprises again, in two ways. First, states are increasingly acquiring direct stakes in firms. This is especially true for firms from non-Organisation for Economic Co-operation and Development (OECD) countries, but increasingly also for Western firms. Second, states increasingly use domestic firms as tools of economic policy. The idea of a homogeneous and mythical 'business world' with its own rationalities, strategies and interests, firmly separated from the public and political realm, seems less and less convincing. Corporations, rather, are becoming ever more public affairs, a trend that has been visible for some years now in Western capitalisms: (hidden) subsidies 
and bail-outs in the end have to be paid by a government. On the other hand, waves of privatizations have led firms to take over public services. This new 'public face of business' raises issues about the accountability, legitimacy and democracy of corporations.

Firms are at the centre of capitalist economies, as investment, production and distribution take place within the confines of the company as a specific legal entity, whether privately run or state-owned. Yet, in recent years and decades, IPE often treated the private and the public as two dichotomous spheres. The analytical distinction between public authorities and private business became reified to an extent that IPE was often reduced to the cross-effects between the two realms of states and markets. As a consequence, firm behaviour tended to be explained predominantly by the virtue of market forces: that is, the rules of the market shape what firms are doing. This comes with a problematic neglect of within-business perspectives, where organizational rationalities and hierarchies have a tremendous effect on firm behaviour. Firms do not act spontaneously, nor are they usually quick to adapt to changing environments; similarly to bureaucracies, they are planned organizations of high institutional complexity, and this characteristic determines firm behaviour as much (if not even more) as the rules of market exchange (Lazonick 1991). As Rebérioux and Roudaut (Chapter 2 in this volume) point out, the hypothesis of achieving higher efficiency for corporations by keeping them 'purely economic' does not hold empirically. However, if private firms are not automatically more efficient, there is no obvious reason why firms should be private at all. Equating 'business' to 'markets' therefore paints an inaccurate picture of firm activity and leads to analytical misconceptions.

Another consequence of this has been the reification of public authorities and private actors as 'pure' instances. The intrusion of private interest into public policy-making has been identified as exceptional as much as the impact of state action on the behaviour of firms. These have been analysed as instances of lobbying, corruption or clientelism, but in a way which underscores how un-normal such relations are. This is the main story of the political power of corporations that dominated IPE (Wilks 2013). However, this story is problematic for empirical and normative reasons. Empirically, as we have seen above, this idea of two distinct realms is hardly realistic; this is well known for Asian and Latin American economies, but increasingly also holds true for Western economies. Recent research, for instance, demonstrates how firms in the liberal heartland of the US systematically benefit from the large resources that the state provides in order to compensate for firms' costs (Block 2008; Mazzucato 2013; Wade 2014). This is even more obvious for firms in the financial sector where the state appears as a partial owner or major creditor. In the 1990s, states sought virtue in the corporatization of public enterprises, mostly for efficiency reasons. Clifton and Díaz-Fuentes demonstrate in Chapter 7 that a progressive impetus for corporatization (to better service the needs and purposes of the public) has quickly been sidelined in favour of a trend towards 'neoliberal corporatization'. The public purpose, in other words, has been by and large marginalized in the process of making public corporations more 'business-like'.

Given the trend of public authorities systematically shifting funds into individual businesses, this raises the normative question whether the public should have more say in how companies are run and which goals they should fulfil. During the heyday of the globalization debate, when the power of corporations was mythically overstated, this question was answered with the help of the global governance construct. As a kind of output legitimacy, the actions of corporations are somehow legitimate if they contribute 
to the global public interest, however defined. But if one takes the issue of legitimacy more seriously, it also relates to the input dimension. Then, it is a logical consequence to assess the activities of corporations by the standards of participation, transparency and accountability, on the firm, industry and national level (Porter and Ronit 2010). From a perspective of democratic governance, corporations would have to be under democratic control if their actions have strong social impacts, both economically (see Chapter 22 by May) but also for human security (see Chapter 19 by Ganson and Wennmann). Further, given their character as public-private entities, such corporations require more legitimacy than is provided by the various CSR schemes (see Graz, Chapter 28 and Kinderman, Chapter 23, in this volume). In other words: if corporations depend on public resources of any kind, why should they not be subject to public interests? This 'stakeholder approach' to the firm is not new. It has been articulated in earlier accounts that highlight the organized character of modern capitalism (see Höpner 2012; Rebérioux and Roudaut, Chapter 2 in this volume). Here, firms are bound by collective interests of a sectoral or political nature, and not solely by the striving for profit, as in liberal capitalism. Corporations then can be conceived of as quasi-public enterprises and not just as the private affairs of their owners.

It is important here to stress that the idea of organized capitalism has been a direct consequence of analyses of modern capitalism in the twentieth century (Sombart 1919; Shonfield 1965). This was characterized by the formation of large enterprises that captured the complexity of capitalist production within single firms. As a consequence, 'the most successful capitalist economies have moved away from market coordination toward the planned coordination of their productive capacities. The movement to planned coordination has not occurred solely, or even primarily, at the level of the state, but at the level of business organization' (Lazonick 1991, p. 13). Thereby, this move towards the large-scale planned organization of economic activity brought a close proximity between the state and big business (Hilferding 1968 [1927], p.460). The separation of ownership and management has been a logical development in the movement towards planned coordination, mirroring the technical administration of public bodies within bureaucracies.

If we observe a revival of the corporation as a public enterprise (as it becomes increasingly the subject of public collective interests), we can interpret the dominance of the shareholder view of the firm as a historical interlude spanning four decades since the early 1980s. Shareholder value then appears as but one way to control the action of corporations while other criteria (for example, democratic) might be invoked as well. The return to a more organized form of capitalism is a realistic option not only because the interests of both public authorities and firms are getting closer to each other, but also because the organizational features of corporations persist: firms tend to grow ever stronger, becoming large and complex organizations, with strong hierarchies within them, and huge power resources vis-à-vis their environment (May and Nölke 2013). Hence, the old argument about the power of MNCs is not obsolete because such firms are less transnational than, for example, ten years ago. They are still large firms with huge powers that are still not subject to public accountability. However, the changes in the global economy over the last two decades made the national level of regulation more important for the control of corporate power.

Therefore, a 'new IPE of the corporation' cannot limit itself to the study of large global 
corporations alone. It has to adopt a more international and comparative stance in order to understand the role of private business in the global economy (Walzenbach 2000; Nölke 2011). This requires a more fine-grained framework of analysis, as follows:

- Addressing the diversity of firms, within national confines and on a global scale, and learning about their characteristics and rationalities. Only then is it possible to understand why particular firms act as they do.

- Seeing the different forms in which states and firms interact. There is no universal one-sided dependency as state-business relations are manifold and are changing quickly. While there are instances where large and globally operating firms (particularly financial firms) leave states relatively powerless, firms are primus inter pares in other countries; and again in other countries, corporations are tools of economic policy-making, both domestically and abroad. Thinking in terms of 'public' versus 'private' interests makes increasingly less sense.

- Thinking beyond the standard view of the firm. Not all firms are controlled by shareholders and run by managers, as financialization creates new corporate rationalities. At the same time, family firms play a huge role across the globe, as well as corporations where other stakeholders than capital owners have a large voice. And in times where particular firms are increasingly becoming the objects of economic policy-making, this poses anew the question about the public role of corporations and their control.

The chapters in this Handbook might be diverse in their subjects and approaches, but they are unified in the way they 'speak' towards such a new agenda of the study of corporations.

\section{THE STRUCTURE OF THE BOOK}

This Handbook should help to promote this 'new IPE of the corporation'. It aims to foster a global perspective through incorporating global perspectives on corporations; not assuming uniformity of corporate power, but acknowledging the diversity of corporations and their institutional and political context. Therefore, its authors come from the US and Europe, but also from Latin America, Asia and Africa. The Handbook hopefully provides ample material for a nuanced discussion of the arguments developed above. However, it should also help to give an overview of the research on corporations over the last decades. It is therefore organized along four main themes which each constitute a part of the book.

Part I deals with the corporation and its stakeholders. It inter alia refutes the implicit assumption of much IPE research that global corporations are all alike and exclusively the prerogative of their owners. Instead, it highlights the public character of the corporation, for example with regard to labour and the public at large. However, the fact that corporate power sits first and foremost in the hands of the management reflects in itself a particular way in which corporations can be organized. Chapter 2 by Antoine Rebérioux and Gwenaël Roudaut therefore provides a concise overview of the main debates in the field of corporate governance and the way it is interpreted today. They highlight that the currently dominant managerial view of corporate governance rests on particular (economic) principles that are themselves contested. The alternative 'stakeholder' approach 
to corporate governance, then, is not just a theoretical perspective but informs much of real-world corporate governance around the world. J.P. Sapinski and William K. Carroll (Chapter 3) aptly demonstrate how the dominance of the managerial view stems not least from a strong concentration of power within and beyond corporations. Through interlocking directorates and the establishment of explicit corporate networks, managers are able to leverage their power while gaining some independence vis-à-vis other stakeholders in their 'own' firm.

In political economy terms, capital and labour are the two central elements of capitalist enterprise. However, compatible with the managerial view of the firm, labour is being delegated to the role of a stakeholder, thereby externalizing labour from the inner core of modern corporations. Drawing on an empirical case, Matthias Ebenau (Chapter 4) demonstrates how management and labour organization represent two political economic 'logics' that constitute a field of struggle and consensus which is inherent to any firm. Sanjay Pinto (Chapter 5) shows that businesses can be organized beyond the 'political economy of capital'. Assessing the historical and theoretical background of co-operatives and alternative forms of business organization, he not only presents 'niches' of corporate activity but also helps in thinking about corporate governance beyond the managerial imperative.

Corporate power is one of the prominent themes of this Handbook because it directly relates to the issue of affected stakeholders. Corporations are able to affect the lives of numerous groups, classes and individuals, and as such, they exercise power. In democratic societies, however, power needs to be controlled or legitimized. Representation of multiple stakeholders in the activities of corporations therefore can be regarded as a necessary condition to legitimize corporate power. As will become clear throughout the individual chapters of the Handbook, corporations are deeply embedded in their social, economic and ecological environment, which affects diverse stakeholders. One of the main questions, then, is how corporate activity supports or overcomes gender inequality. Obviously, modern large corporations are structured unequally when it comes to the gender dimension, starting with the gender pay gap and not ending with the under-representation of women in top management. Catia Gregoratti, Adrienne Roberts and Sofie Tornhill (Chapter 6) critically assess whether the diverse projects of women's empowerment in corporations actually help to tackle gender inequality. More fundamentally, they show how feminist movements criticize such empowerment projects as cases of feminist co-optation.

Broadening the field of corporate stakeholders, the next two chapters highlight the interests of the state and public institutions in corporate activity as well as the demands of 'illegitimate' stakeholders that seek to influence corporations by illegal means. Judith Clifton and Daniel Díaz-Fuentes (Chapter 7) provide a solid theoretical background for a discussion about public corporations, that is, corporations over which the state exercises fundamental control. Public corporations are often present in sectors which were previously organized by public bureaucracies but in which privatization (or 'corporatization') reorganized them along private corporate lines. Prominent sectors include energy, telecommunications, transportation and the defence industry, indicating that a significant share of a nation's economy is organized through public corporations. However, the ways and processes through which sectors are corporatized varies, and is subject to conflicting interests by management, shareholders and the general public. While public actors are without doubt legitimate stakeholders to firms, there are also illegitimate stakeholders 
who claim access to the resources provided by corporations. Bribery, corruption and other extra-legal activities denote the ways in which actors engage who are by law not entitled to enjoy the benefits they aspire to from corporations. However, Markus Pohlmann and Julian Klinkhammer argue in Chapter 8 that legal rules alone are insufficient to explain such behaviour: bribery and corruption might be not legal or legitimate, but nevertheless are effective from an organizational point of view. Their concept of 'organizational deviance' directs our attention to the persistence of illegal corporate behaviour despite the proliferation of anti-corruption policies and campaigns. It is precisely the functionability of corruption for 'the good of the company' that is often overlooked in analyses of empirical cases and the phenomenon of bribery and corruption as a whole.

Part II of the Handbook highlights the different national institutional contexts under which corporations are operating. In particular, it comprises studies showing how national governments have developed a broad range of pro-business policies, against the common assumption that states only set the basic framework conditions under which the economy operates and that there is one best way of implementing these conditions. Part II therefore also provides a geographical overview of how national institutional contexts differ and how this matters for the analysis of corporations. In Chapter 9, Sandra Eckert sketches the institutional configurations of Western business systems, particularly with regard to the classic arguments of the 'varieties of capitalism' research tradition and the further theoretical developments that rest upon it. By doing so, she also reminds readers of the underlying theoretical argument of this tradition: complementarities among institutions create coherence and stability, which in turn has positive effects on corporate strategies as firms have stable expectations about their environment. Whether this actually materializes empirically, and under which circumstances, are matters open for debate, and many contributions to this Handbook do so in constructive and insightful ways. Yet, 'institutional embeddedness', we would argue, is more than a simple context variable: it shapes corporate action much more strongly than expected by approaches that focus on firm strategy alone. This also becomes visible in the contribution of Vera Śćepanović and Dorothee Bohle (Chapter 10), who convincingly demonstrate how the institutional framework shapes the strategies of foreign firms in Central and Eastern Europe. What they describe as 'dependent capitalism' manifests itself in the particular ways of how transnational corporations organize their profit-making activities, usually in different ways than in other regions. Firms and their institutional contexts constitute relatively stable economic systems which, at least for some time, are able to yield growth and relative competitiveness; which, however, comes at a price. Turning to yet another geographical region, Michael A. Witt (Chapter 11) offers an overview of the world of Asian business systems. Not only are Asian firms internally very different from Western firms (as we discussed above), but their institutional contexts differ significantly as well. Witt particularly sheds light on the implications of the differences of business systems (as a holistic phenomenon) on the cultural and strategic parameters of managerial action in and across Asian firms. Although it summarizes the vast variety of Asian business systems in a few broad brush strokes, Witt's chapter makes a strong point in demonstrating the micro-macro connection of institutional approaches in the study of corporate behaviour.

In Chapter 12, Alexandra Dienes (née Vasileva) provides a thorough analysis of that segment of firms which deal with natural resources. Some of the biggest firms worldwide are from the natural resources sector; they deserve particular attention not just because of their 
size but also because of the politico-economic effects they have on the national and regional scale. Dienes looks closely at the Russian case, where the names Rosneft and Gazprom are probably well known. However, less is known about the precise entanglement of both firms in the Russian political economy. The chapter also provides a primer on the issues of the resource curse and Dutch disease problems, together with a discussion of patrimonial capitalism as an institutional effect of the strong position of resource corporations. These three phenomena are regularly discussed in the context of resource-rich countries (with resource corporations acting as rational vehicles for the extraction and marketing of gas, oil and other resources). Therefore, Dienes's chapter also provides a foundation to discuss the effects of resource corporations beyond the Russian or Arab regions.

Families often strongly influence corporate behaviour, yet the role of families in corporations has hardly been studied from an institutional point of view. The classic 'varieties of capitalism' approach, for instance, distinguishes between coordinated and market-based systems of corporate governance but largely overlooks that - even in the emblematic cases of the US and Germany - family businesses play a significant role. This is even more true for non-OECD countries. Even where family firms are partially under shareholder control, this creates another logic of corporate control that potentially competes with shareholders. Diego Finchelstein (Chapter 13) therefore discusses the scope and importance of family corporations around the world in order to help observers to better understand why and how family firms act according to different motives compared to firms with a widely dispersed ownership. Obviously, the state is a major element in the domestic embeddedness of corporations. As an owner of businesses, it acts like an entrepreneur itself (as demonstrated by Clifton and Díaz-Fuentes in Chapter 7), but at the same time it serves as an important element in the institutional context of corporations as it provides incentives and constraints for private corporations. Moisés V. Balestro (Chapter 14) addresses the role of the state in assisting domestic multinational firms, through the lens of the Latin American experience, where this role has been played prominently. By 'pushing' domestic firms into the global economy through actively supporting their transnationalization efforts, the state follows a foreign economic policy that is not limited to trade and monetary policy alone (which would set the policy context in which firms deploy their international strategies), but uses its direct influence on corporations. By doing so, the corporate power of selected multinationals is to a large extent a result of national bureaucracies' efforts to actually empower them in order to penetrate global markets. Speaking of empowerment, Hwok-Aun Lee and Lumkile Mondi (Chapter 15) show how corporations are embedded in legal frameworks as well. In their chapter, they demonstrate how the societies in Malaysia and South Africa place a strong emphasis on minority rights, which are codified in national laws and are aimed at empowering disadvantaged groups. However, effective implementation of minority rights would, inter alia, require corporations to adhere to these rights, which is why both countries established affirmative action schemes that shape the strategies of firms. Similar to the gender equality problem addressed in Chapter 6 by Gregoratti, Roberts and Tornhill, there is the political question of whether firms can be effective agents or instruments in the realization of equality-related policies or whether they would have to be obliged to adhere to policies of gender equality of minority rights. As these chapters show, the legal institutional context matters a lot for the effectiveness of firms in responding to social norms and principles. 
Part III addresses multinational corporations more specifically. As argued earlier, the view that big corporations sit at the apex of global investment chains, thereby taking the helm of global economic activity and being able to act upon their discretion alone, is still relatively prominent. Yet, the corporate reality is much more complex. We have already hinted at some of the barriers, obstacles and limits to absolute corporate power. The contributions in Part III highlight the importance of negotiations within multinational corporations, as well as between MNCs and governments that constantly seek to impose their priorities upon these companies. They highlight, from various angles, that a corporation's activity across borders usually comes at a price, and is often not a smooth process but involves conflict and tensions. By providing a historical overview of theories, practices and policies relating to multinational corporations, Filip de Beule and Andreja Jaklič (Chapter 16) give a concise account of what can and should be understood by MNCs. They also shed light on the effects of MNC activity on home and host countries, in particular their impact on the development of the latter. However, whether and how MNCs have a beneficial effect on home or host countries depends not least on their internal capacity to organize efficiently. More concretely, the assumption that MNCs generally drive up capital intensity, increase productivity, provide jobs and enhance expertise in host countries requires first and foremost that they are internally organized in a way that enables them to be efficient, regardless of their transnational activity. The organizational complexity of multinational firms, however, is considerable higher than for 'national' firms, and MNCs are faced with the challenge to organize not just transnational production chains but also transnational management relations.

In Chapter 17, Glenn Morgan raises the diverse challenges that MNCs have to face with respect to the relations between the headquarters and subsidiaries. Although both entities belong to the same corporation, each has organizational interests of their own which they try to push forward. Morgan highlights the power relation between headquarters and subsidiaries, that puts the image of the unified MNC into context: the headquarters seeks to keep subsidiaries under close control, but subsidiaries aspire independence or autonomy from headquarters which they seek to achieve by way of subversive strategies. Although the headquarters can place senior managers into subsidiaries, the MNC as a whole still depends on the knowledge of local managers about local labour relations, supplier relations or legal frameworks to ensure the effectiveness of its operations. Hence, there are substantial organizational limits to the power of MNCs. The same holds for the relations of MNCs with host countries, as Caner Bakir and Judith Woods demonstrate in Chapter 18 by presenting the different ways in which such bargaining takes place and how this affects the strategies and outcomes of both host states and MNCs.

Another dimension in which MNCs can affect host countries in a direct, political way is their involvement in violent conflicts. As Brian Ganson and Achim Wennmann show (Chapter 19), the record of corporate violence, corporate activity in or tolerance of violent actions, is rich; but again, the picture is more complex: corporations can cause violent conflict, but they also serve as a solution to conflict (the 'business for peace' programme). Often, the question is not whether corporations are the problem or the solution, but how they are entangled with the intertwined relations that are characteristic of deep-seated conflicts. It is necessary to get a sense of this complex picture in order to grasp the role of corporations in violent conflict in an analytical fashion, and Ganson and Wennmann's 
chapter provides a good starting point for any meaningful discussion on that topic in classrooms and offices.

As we indicated earlier, the role of corporations became one of the most important and most discussed topics in the global political economy. Astonishingly, however, there is no multilateral investment regime, let alone an institution that would organize and shape the international investment landscape. Still, transnational investment is governed through bilateral or regional treaties and provisions in multilateral trade agreements. Tarald Laudal Berge and Helge Hveem (Chapter 20) therefore pose two central questions in their chapter: (1) why is there no multilateral agreement for protecting investment?; and (2) would such an agreement be needed? Considering the first, they correctly speak of 'failed multilateralism'; regarding the second, they point to the tension between countries and negotiators who are content with the current bilateral and largely technical investment regulations, and the wider public who push for stronger transparency, especially within the current Trans-Pacific Partnership (TPP) and Transatlantic Trade and Investment Partnership (TTIP) negotiations. The last chapter in Part III, Chapter 21 by Okechukwu C. Iheduru, deals with African corporations and the issue of 'Africapitalism'. Why has this chapter been included? Because Iheduru makes a powerful argument that African businesses have a strong regional character. It is not just that the most important African firms are multinational by nature, because they never focus on their home country alone but always engage with the wider African region; it is also because their African identity is a major element in their drive for internationalization and regional integration. Extremely rich in its discussion of the field as well as empirical information, Iheduru's chapter is probably one of the best places to start exploring African multinationals, which have been overlooked by almost the whole IPE field up to now.

Part IV of the book finally takes issue with the assumption that global corporations are the masters of the global economy, by setting rules via corporate standards and pressuring governments into certain policies. For this reason, the remaining chapters address a range of policy areas in which corporations arguably have a strong influence. As many contributors argue, corporations are indeed powerful global players, but they have to share their powers with others, in particular with the national governments of powerful states. Furthermore, their powers give rise to regulatory considerations which have direct implications for any approach to democratic governance. In Chapter 22, Christopher May depicts the corporation as an institution of global governance in itself. The simple fact that corporations move goods, resources, labour power, rules and practices around the globe makes them prime shapers of the livelihoods of many individuals, countries and societies. Hence, corporations undertake governance functions, and this poses at least two questions: (1) how can this governance be improved?; and (2) why has the 'democratic deficit' of global governance through firms not been adequately addressed? The latter question is taken up by Daniel Kinderman in Chapter 23 on global standards and CSR. Similarly to May, Kinderman argues that the sheer extent of corporate power understandably gave rise to global CSR initiatives and an intensified problematization of corporations' legitimacy. He provides an overview of the rise of CSR politics and scholarship, arguing that there are two broad strands addressing CSR: a normative one and a regulatory one. However, it is interesting to see how the chapters by May and Kinderman differently map the discursive field: in Kinderman, the problem is one of democratic legitimacy and regulation, while for May it comes down to a democratic deficit. Yet, 
together, they provide a lens through which corporate power can be assessed; not just for the remaining chapters, but actually for the whole Handbook and beyond.

Any IPE student interested in corporations as global players cannot ignore the role of finance firms in the global economy. During the last three to four decades, the global political economy has been increasingly shaped by financial corporations, especially in relation to manufacturing firms. As a consequence, the 'TNC view' of the global corporation only partially grasps global corporate power. Although a single Handbook chapter cannot sufficiently cover all the dimensions that this change entails, Kevin Young (Chapter 24) successfully presents a useful framework to analyse the influence of finance firms by looking at how they are able to set agendas through their normal business activity, how they directly target policy-makers and regulators through advocacy efforts, and how they are represented in global elite networks. Thereby, Young's chapter serves as a good starting point for further inquiry into the role of financial corporations.

Having covered the areas of global investment and finance, a crucial area where corporations have a strong influence is in global trade policy-making. After providing a concise overview of the main economic and political theories of trade policy, Jappe Eckhardt (Chapter 25) turns his attention to the position of firms in the global trade system, and how they use the World Trade Organization Dispute Settlement Body, but also other bilateral and multilateral arrangements through forum-shopping in trade policy. He also emphasizes that firms are increasingly dependent on imports and exports, which point is taken up by Liam Campling and Benjamin Selwyn in Chapter 26 on value chains and the world economy. Multinational corporations often do not trade on spot markets, but through managed trade and inter-firm trade arrangements. Such forms of trade are in turn related to FDI activities of corporations, which add to a complex picture of transnational production. In between the ideal types of corporations producing 'at home' and exporting goods on the one hand, and investing capital into host countries to set up production facilities on the other hand, contemporary production of commodities is a complex mix of both. The analytical imperative, then, is to understand how added value is created and traded across global production chains. Campling and Selwyn not only provide a succinct introduction to the evolution of the concept and theories of GVCs, but formulate important criticisms and alternative approaches that are relevant to the IPE study of corporations in contemporary global capitalism. The latter is particularly important, because GVC theory tends to portray global production processes through the lens of a predominantly managerial view of effective governance of such chains, thereby neglecting contradictions and resistances that are ever present in and across corporations (we only have to recapitulate the arguments made by Ebenau in Chapter 4, Pohlmann and Klinkhammer in Chapter 8, Morgan in Chapter 17, and Bakir and Woods in Chapter 18). However, readers particularly interested in GVC are welcome to consult Chapter 22 by May and Chapter 23 by Kinderman, who both argue that the control of value chains raises concerns about democratic control and accountability; Chapter 28 by Graz and Chapter 27 by Gumbert and Fuchs on the concentration of power and rule-making through particular forms of global value chain governance; and Chapter 25 by Eckhardt on the effect of different forms of value chains on trade policy strategies.

The contradictions and resistances of global trade become clearly visible when we look more closely at a certain area of corporate activity: global food governance. On the one hand, corporate power is very strong, culminating in the concentration process 
in the retail industry and the hierarchization of food value chain governance (Gereffi et al. 2005). On the other hand, the organization of complex value chains is complex, and Tobias Gumbert and Doris Fuchs (Chapter 27) demonstrate that considerable opposition is coming from the consumer side. Emanating from this constellation, Gumbert and Fuchs are able to formulate two future scenarios for the global food industry which centre around the future of the 'industrial food complex' and alternatives to it. The food sector is, as Gumbert and Fuchs show, a prime example of the complex power of corporations through private standard-setting. In Chapter 28, Jean-Christophe Graz puts this issue of standardization into a coherent global picture. He shows how and why corporations are able to create standards which work in their interests, especially concerning market regulation standards which would usually be under public supervision. Corporations benefit, as Graz argues, from a complex constellation between different territorial entities, actors, issues and standard-setting procedures which he refers to as the 'transnational hybrid authority of standards'.

Hence, the final chapter again relates to a common theme of the Handbook: corporations have the capacity to exercise power through their daily operations, through advocacy and lobbying activities, through shopping between fora and territories and, not least, through the establishment of genuinely private standards and institutions. But yet, this complexity needs to be actively managed by corporations. Firms can make use of this complex constellation in order to enhance their power and influence, but they can also become paralyzed because they are organizationally unable to work with this complexity. Furthermore, the fields in which (transnational) corporations are active are highly dynamic: conditions change quickly within sectors, the institutional and political context might change quickly, and there are political dynamics that shape the support for or resistance against corporate behaviour. In any case, after reading the individual chapters the bold brush stroke idea of 'corporations ruling the world' will be heavily qualified. Therefore, the editors hope that this Handbook serves as a helpful guide through the contemporary corporate landscape and the most intricate issues for IPE students in order to stimulate meaningful and important ideas for further research.

\section{NOTE}

1. Acknowledging the conceptual differences between multinational and transnational corporations, both terms refer to firms that are active in multiple countries. For the purposes of this introductory chapter, we use the term MNC for any firm that is multinationally or transnationally active.

\section{REFERENCES}

Aoki, Masahiko and Ronald P. Dore (eds) (1994), The Japanese Firm: Sources of Strength, Oxford: Oxford University Press.

Block, Fred (2008), 'Swimming against the current: the rise of a hidden developmental state in the United States', Politics and Society, 36 (2), 169-206.

Carroll, William K. (2010), The Making of a Transnational Capitalist Class: Corporate Power in the Twenty-First Century, London, UK and New York, USA: Zed Books.

Clift, Ben (2014), Comparative Political Economy: States, Markets and Global Capitalism, Houndmills, Basingstoke: Palgrave Macmillan. 


\section{Handbook of the international political economy of the corporation}

Coen, David, Wyn Grant and Graham Wilson (2010), 'Political science perspectives on business and government', in David Coen, Wyn Grant and Graham Wilson (eds), The Oxford Handbook of Business and Government, Oxford: Oxford University Press, pp.9-34.

Dicken, Peter (2011), Global Shift. Mapping the Changing Contours of the World Economy, New York, USA and London, UK: Guilford Press.

Dore, Ronald P. (1973), British Factory-Japanese Factory: The Origins of National Diversity in Industrial Relations, Los Angeles, CA: University of California Press.

Doremus, Paul N., William W. Keller, Louis W. Pauly and Simon Reich (1998), The Myth of the Global Corporation, Princeton, NJ: Princeton University Press.

The Economist (2017), 'The retreat of the global company', The Economist, 28 January.

Frieden, Jeffry and Ronald Rogowski (1996), 'The impact of the international economy on national policies: an analytical overview', in Robert O. Keohane and Helen V. Milner (eds), Internationalization and Domestic Politics, New York: Cambridge University Press, pp. 25-47.

Fuchs, Doris (2007), Business Power in Global Governance, Boulder, CO: Lynne Rienner.

Gereffi, Gary, John Humphrey and Timothy Sturgeon (2005), 'The governance of global value chains', Review of International Political Economy, 12 (1), 78-104.

Gill, Stephen R. and David Law (1989), 'Global hegemony and the structural power of capital', International Studies Quarterly, 33 (4), 475-499.

Gilpin, Robert (1975), US Power and the Multinational Corporation, New York: Basic Books.

Gilpin, Robert (1987), The Political Economy of International Relations, Princeton, NJ: Princeton University Press.

Gourevitch, Peter A. and James Shinn (2005), Political Power and Corporate Control: The New Politics of Corporate Governance, Princeton, NJ: Princeton University Press.

Graz, Jean-Christophe (2003), 'How powerful are transnational elite clubs? The social myth of the World Economic Forum', New Political Economy, 8 (3), 321-340.

Heemskerk, Eelke M. and Frank W. Takes (2016), 'The corporate elite community structure of global capitalism', New Political Economy, 21 (1), 90-118.

Hilferding, Rudolf (1968 [1927]): Das Finanzkapital, Frankfurt am Main: Europäische Verlagsanstalt.

Höpner, Martin (2012), 'Coordination and organization: the two dimensions of nonliberal capitalism', Max Planck Institute for the Study of Societies, MPIfG Discussion Paper 07/12.

Katzenstein, Peter J. (ed.) (1978), Between Power and Plenty: Foreign Economic Policies of Advanced Industrial States, Madison, WI: University of Wisconsin Press.

Keohane, Robert O. and Helen V. Milner (1996), 'Internationalization and domestic politics: an introduction', in Robert O. Keohane and Helen V. Milner (eds), Internationalization and Domestic Politics, New York: Cambridge University Press, pp. 3-23.

Korten, David C. (1995), When Corporations Rule the World, Oakland, CA: Berrett-Koehler Publishers.

Lazonick, William (1991), Business Organization and the Myth of the Market Economy, Cambridge: Cambridge University Press.

Lindblom, Charles E. (1977), Politics and Markets: The World's Political Economic Systems, New York: Basic Books.

May, Christian and Andreas Nölke (2013), 'Vergleichende Kapitalismusforschung im Zeitalter der Krise der Finanzialisierung: Vom inter-nationalen zum inter-temporalen Studium ökonomischer Institutionen', Zeitschrift für Außen- und Sicherheitspolitik, 6 (1), 51-70.

Mazzucato, Mariana (2013), The Entrepreneurial State: Debunking Public vs. Private Sector Myths, London: Anthem Press.

Moravcsik, Andrew (1997), 'Taking preferences seriously: a liberal theory of international politics', International Organization, 51 (4), 513-553.

Murray, Georgina and John Scott (eds) (2012), Financial Elites and Transnational Business: Who Rules the World?, Cheltenham, UK and Northampton, MA, USA: Edward Elgar Publishing.

Musacchio, Aldo and Sergio G. Lazzarini (2014), Reinventing State Capitalism: Leviathan in Business, Brazil and Beyond, Cambridge, MA: Harvard University Press.

Nölke, Andreas (2011), 'Transnational economic order and national economic institutions: comparative capitalism meets international political economy', Max Planck Institute for the Study of Societies, MPIfG Discussion Paper 11/3.

Nölke, Andreas, Tobias ten Brink, Simone Claar and Christian May (2015), 'Domestic structures, foreign economic policies and global economic order: implications from the rise of large emerging economies', European Journal of International Relations, 21 (3), 538-567.

Porter, Tony and Karsten Ronit (eds) (2010), The Challenges of Global Business Authority: Democratic Renewal, Stalemate, or Decay?, New York: SUNY Press.

Robinson, William I. and Jerry Harris (2000), 'Towards a global ruling class: globalization and the transnational capitalist class', Science and Society, 64 (1), 11-54. 
Shonfield, Andrew (1965), Modern Capitalism: The Changing Balance of Public and Private Power, Oxford: Oxford University Press.

Sklair, Leslie (2001), The Transnational Capitalist Class, Oxford: Wiley-Blackwell Publishing.

Sombart, Werner(1919), Der moderne Kapitalismus. Historisch-systematische Darstellung des gesamteuropäischen Wirtschaftslebens von seinen Anfängen bis zur Gegenwart, München and Leipzig: Duncker \& Humblot.

Stopford, John M. and Susan Strange (1991), Rival States, Rival Firms: Competition for World Market Shares, Cambridge: Cambridge University Press.

Strange, Susan (1988), States and Markets, London: Pinter.

Strange, Susan (1992), 'State, firms and diplomacy', International Affairs, 68 (1), 1-15.

Strange, Susan (1996), The Retreat of the State: The Diffusion of Power in the World Economy, Cambridge: Cambridge University Press.

Strange, Susan (1998), Mad Money: When Markets Outgrow Governments, Ann Arbor, MI: University of Michigan Press.

UNCTAD (2007), The Universe of the Largest Transnational Corporations, New York, USA and Geneva, Switzerland: UNCTAD.

UNCTAD (2017a), World Investment Report, Geneva: UNCTAD.

UNCTAD (2017b), 'UNCTADStat Database', accessed 12 September 2017 at http://unctadstat.unctad.org.

Wade, Robert H. (2014), "Market versus state" or "market with state": how to impart directional thrust', Development and Change, 45 (4), 777-798.

Walzenbach, Gunter (2000), 'The doubtful handshake: from international to comparative political economy', in Thomas C. Lawton, James N. Rosenau and Amy C. Verdun (eds), Strange Power, Aldershot: Ashgate, pp. 369-389.

Whitley, Richard (1999), Divergent Capitalisms: The Social Structuring and Change of Business Systems, Oxford: Oxford University Press.

Wilks, Stephen (2013), The Political Power of the Business Corporation, Cheltenham, UK and Northampton, MA, USA: Edward Elgar Publishing.

Witt, Michael A. (2014), 'Japan: coordinated capitalism between institutional change and structural inertia', in Michael A. Witt and Gordon Redding (eds), The Oxford Handbook of Asian Business Systems, Oxford: Oxford University Press, pp. 100-122.

Yamamura, Kozo and Wolfgang Streeck (eds) (2001), The Origins of Nonliberal Capitalism: Germany and Japan in Comparison, Ithaca, NY: Cornell University Press.

Zingales, Luigi (2016), 'Donald Trump, crony capitalist', New York Times, 23 February. 
Christian May and Andreas Nölke - 9781785362538 Downloaded from PubFactory at $04 / 26 / 2023$ 01:22:59PM via free access 